\title{
Breeding and embryonic development of Hampala macrolepidota (Van Hasselt and Kuhl, 1823).
}

\begin{abstract}
The present study investigated the breeding and embryonic development of sebarau, Hampala macrolepidota from fertilization until early hatched. The matured eggs and sperm were obtained by induced breeding using a commercial hormone, ovaprim. Dosages given for female and male were 0.6 and $0.3 \mathrm{~mL}$ ovaprim kg- 1 b.wt., respectively. Fertilized eggs were adhesive, spherical and sticky. Fecundity for females weighing 180-280 g ranged from 34,985-75,646 eggs/fish. Average diameter of the fertilized eggs ranged from $0.55 \pm 0.13-$ $1.06 \pm 0.36 \mathrm{~mm}$. Fertilization rates ranged from $18-28 \%$ after $24 \mathrm{~h}$ incubation. The observation on the embryonic development covers various stages from newly fertilized eggs, cell division, epiboly, somites until hatched.
\end{abstract}

Keyword: Breeding; Embryonic development; Hampala macrolepidota; Sebarau. 